УДК 78+793.3]:394.23

Катерина СТАНІСЛАВСЬКА

\title{
АРТМОБ: ХУДОЖНЯ АКЦІЯ У ПРОСТОРІ ВУЛИЧНОГО МИСТЕЦТВА
}

Стаття презентує погляд на естетичний різновид флешмобу - артмоб - як сучасне втілення художньої акції. Розглянуто інструментальний, вокальний та танцювальний артмоби; наведено приклади.

Ключові слова: флешмоб, артмоб, художня акція, вуличне мистецтво.

Статья представляет взгляд на эстетический вид флешмоба - артмоб-как современное воплощение художественной акиии. Рассмотрены инструментальный, вокальный и танцевальный артмобы; приведены примеры.

Ключевые слова: флешмоб, артмоб, художественная акиия, уличное искусство.

The article presents the view on the aesthetic appearance of the flash mob - art mob as a contemporary embodiment of the artistic action. Instrumental, vocal and dance art mobs are considered; examples are given.

Key words: flash mob, art mob, artistic action, street art.

У сучасних умовах суцільної інформатизації особливою популярністю користуються різні моделі віртуальної взаємодії - зокрема, мережеві спільноти. Одним з напрямів життєдіяльності подібних спільнот $є$ творчо-ігрові форми, прикладом яких став флешмоб та його різновид артмоб. 3 часу виникнення флешмобу минуло лише п'ятнадцять років, але він уже став однією з найулюбленіших видовищно-ігрових практик у сучасному соціумі. Здається, настав час поміркувати про природу артмобу, особливості його існування та поширення.

Великі соціальні мережі (релігійні, політичні, навіть терористичні тощо) існували завжди, але засоби комунікації в них були недосконалими. Розвиток комп'ютерних технологій кінця XX початку XXI ст. надав мережевим організаціям нових комунікаційних можливостей, поступово сформувавши віртуальні спільноти. Таким спільнотам, крім особливої мови, власних цінностей та інтересів, притаманна здатність утворювати спільні дії у кіберпросторі та поза ним. Ці дії, організовані через Інтернет-мережу, досить часто мають ігровий характер.

Однією з таких форм і $є$ флешмоб. Флешмоб (англ. flash - спалах, мить; mob - натовп) - заздалегідь спланована через Інтернет масова акція, у якій група людей раптово, несподівано для перехожих, з'являється у визначеному громадському місці, виконує впродовж нетривалого часу певні оговорені дії, після чого дуже швидко «розчиняється». Перші флешмоби відбулися влітку 2003 р. у багатьох містах Америки, Свропи, Японії, країн СНД.

Організація флешмобу відбувається анонімно через спеціалізовані сайти, де кожен охочий може зареєструватися, пропонувати свої сценарії та голосувати за сценарії інших. Ідеальним вважається сценарій, що буде абсурдним, загадковим, не дуже помітним і не провокуватиме сміх: дії мобберів мають здаватися випадковим глядачам безглуздими, однак виконуватись вони повинні так, ніби в цьому є сенс. Анонімність флешмобу виявляється і в тому, що охочі взяти участь у флешмобі до моменту здійснення акції не знають, скільки буде учасників.

Основними принципами флешмобу є: спонтанність (учасники не збираються на місці події до початку акції, адже має справлятися враження, що моббери - такі само випадкові перехожі, як і інші люди); відсутність рекламних чи фінансових цілей (ніхто з учасників не платить і не отримує грошей); заборона висвітлення події у 3МІ до іiі проведення; абсурдність сценарію, який не 
піддається логічному обгрунтуванню (флешмоб має викликати не сміх, а подив).

Цікавий підхід до феномена флешмобу пропонує М.Жаркова, розглядаючи його у контексті поняття «молодіжний субпотік». Останній дослідниця визначає «постмодерністською стадією розвитку молодіжних субкультур» [4, 7], відносячи його до явища постсубкультури. Під молодіжними постсубкультурами авторка розуміє субкультурні явища, що мають гедоністичне спрямування і не містять антисоціального змісту, натомість виконують комунікативно-компенсаторні та креативно-стимулюючі функції. Відповідно, субпотік виникає внаслідок об'єднання масових потоків бажань індивідів, що знайшли самовираження в отриманні задоволення, почуття свободи та творчої самореалізації. Тому, на думку авторки, флешмоб $€$ типом ігрового молодіжного субпотоку, в якому реалізовані принципи загальної рівності, процесуальності, пріоритету змісту над іміджем, відкритості, тимчасовості й раптовості $[4,10-11]$.

Схожий шлях у дослідженні флешмобу обрала дослідниця А.Петренко-Лисак, оперуючи концептом «соціальна рухливість». Справедливо стверджуючи, що флешмоб не $\epsilon$ соціальним рухом, авторка доводить його належність до проявів соціальної рухливості. Так, флешмобу не вистачає ідейності та конвенціональності, він не породжує соціальні норми та цінності, проте використовує ï як підгрунтя для об'єднання прихильників масових, публічних акцій. Соціальна рухливість флешмобу виявляється у тимчасовому зрушенні соціальної свідомості та поведінки [6, 27-29]. Ще одна властивість флешмобу, яку хочеться відзначити у цьому контексті, — «неослабний пафос подолання меж». Моббери ніби перемагають об'єктивні сили простору, часу, соціального розшарування [3, 55].

Розглядаючи флешмоб у комунікативному аспекті, дослідники С. Демченков та Н. Паршаніна доходять логічних висновків. Флешмоб не вписується у вже наявні концепти міжособистісної та масової комунікації («оne to one», «one to all», «all to all») і вимагає формування ще однієї комунікативної моделі - «nobody to nobody». Набуваючи дедалі більш дифузної спрямованості, повідомлення сучасних ЗМК врешті-решт зовсім позбавляються адресності. Знеособлена комунікація, народжена Інтернетом, ілюструється і вуличним флешмобом $[2,75]$. Отже, в результаті взаємодії віртуального та реального просторів стає можливою специфічна форма соціальної комунікації - повідомлення, передане ніким нікому і ні про що $[2,78]$.
Останнім положенням пояснюється неприховане здивування випадкових свідків перших флешмоб-акцій, що відбулися у 2003 р., зокрема таких: 300 людей зайшли до книгарні й попросили неіснуючу книгу (Рим); кілька сотень відвідувачів меблевого магазину сказали одну фразу: «Вау, оце так диван!» (Лондон); сто перехожих на вулиці одночасно зняли по одному черевику і постукали ним по бруківці (Сан-Паулу); кілька десятків людей у чорних окулярах плескали в долоні і фотографували «об'єкт пальму» у торговельному центрі (Київ, перший український флешмоб у «Глобусі»); півсотні людей у чорному зі скорботним видом поклали по дві квітки до ніг клоуна перед «Макдональдсом» (Одеса). У таких та подібних акціях найпривабливішим для мобберів $є$ отримання швидкого відгуку містян через початковий подив, подальший інтерес та фінальний виплеск тієї чи іншої реакції.

Отже, флешмоб безперечно має карнавальний характер, видовищну природу, театральний компонент демонстрації-презентації та яскраво виражений ігровий контекст. Останній виявляється не лише у наявності правил та виконанні ролей, а й у пріоритеті процесу над результатом. Названі особливості уможливлюють тлумачення флешмобу як новітньої форми акціонізму, поряд з «давнішніми» хепенінгом, перформансом, акцією. Маючи певні перетини і з перформансом, і з хепенінгом, флешмоб, на нашу думку, є новітнім втіленням акції, котра, як відомо, здійснюється у громадському місці, розрахована на непідготовлену публіку і має, як правило, разовий характер.

Одним з естетизованих різновидів флешмобу, що впритул наближує художню акцію до стріт-арту, $є$ артмоб - акція, що має певну художню цінність, адже спільні дії, виконувані мобберами, передбачають презентацію мистецького продукту. Саме тому артмоб порушує основне правило флешмобу - анонімність: моббери готують свій «номер» заздалегідь, проводять репетиції. Втім, інші умови та правила зберігаються: акція проводиться у публічному, громадському місці без явної підготовки, виникаючи для глядача неочікувано і спонтанно. Виконавці артмобів не повинні зовні виділятися з натовпу, тому в таких акціях не застосовуються уніформа, костюми, маски, спільні аксесуари чи реквізит. Арт-моб це «перформанс, організований за принципами флешмобу» [3, 52].

Дослідниця М. Веселова вважає, що артмоб як культурний текст, що описує міську специфіку та особливий місцевий колорит, фокусується на кризі у стосунках людини та міського середо- 
вища, що спостерігається сьогодні. I тому він дає змогу людині не лише інтегруватися у довкілля через художній об'єкт, а й відчути себе вільним від суспільних стереотипів та спробувати себе у різних поведінкових сценаріях [1, 79-80].

Артмоби можна поділити на три основні групи: інструментальні, вокальні, танцювальні, і вже з назви стає зрозумілим, яку мистецьку форму презентує кожна 3 груп. Інструментальне виконавство, звісно, передбачає наявність музичних інструментів: як правило, вони з'являються ніби нізвідки, а музиканти приєднуються до спільного музикування поступово.

Так, у квітні 2012 р. у метро Копенгагена відбувся артмоб за участю філармонійного оркестру, котрий під час руху виконав фрагмент «Ранку» $з$ сюїти «Пер Гюнт» Едварда Гріга. У випадку цієї акції відбулася певна підготовка пасажира-слухача: на табло, де з'являється інформація про прибуття потягів, пройшла інформація, що зараз прибуває спеціальний музичний поїзд, 3 побажанням насолоджуватися музикою. Утім, зважаючи на відеозапис, мало хто 3 пасажирів звернув на це увагу чи зрозумів, про що йдеться. У заповненому вагоні починають лунати звуки флейти, потім приєднуються інші інструменти: дивним чином окремі пасажири метро виявляються музикантами. Люди, що опинилися всередині «гріговського лісу», реагують вкрай позитивно: дехто розчулений чи захоплений, хтось дивується чи щиро радіє. Така реакція людей переконує у безперечній щиросердності та найвищій гуманності подібних акцій (https://www. youtube. com/ watch?v=gww9_S4PNV0).

Вокальні артмоби представлені переважно хоровим співом, який теж «виникає 3 натовпу». Найчастіше це буває музика академічної традиції, що дає можливість, за влучним виразом О. Крилової, створити «просторово-часові лакуни, наповнені аурою духовності», а паралельно - популяризувати і саме мистецтво, і конкретний колектив $[5,44]$.

Так, у листопаді 2010 р. у канадському місті Велланд (провінція Онтаріо) подібний артмоб могли спостерігати відвідувачі кафе у торговельному центрі Seaway Mall: зазвучала музика, і дівчина «з натовпу», начебто розмовляючи по телефону, почала співати відомий фрагмент з ораторії Генделя «Месія» — «Алілуя». На другій фразі iï підтримав хлопець з іншого боку кафе, потім почали приєднуватися ще й інші хористи. По завершенні номера кілька десятків співаків миттєво «розчинилися» серед відвідувачів фаст-фуду, присівши за столики по всьому залу, — начебто нічого і не відбулося (https://www. youtube. com/ watch?v=SXh7JR 9oKVE).

Досить незвично хоровий спів сприйматиметься і у просторі бібліотеки: саме такий артмоб був влаштований у читальній залі публічної бібліотеки іспанської провінції Вальядолід у червні 2012 р.: такою акцією бібліотека вирішила краще наблизитися до свого читача, влаштовуючи артмоб напередодні Всесвітнього дня музики. Окремі читачі «спалахнули у натовпі», перетворившись на співаків, а після співу знову занурилися у читання (https://www. youtube. com/ watch? $\mathrm{v}=\mathrm{YCm} 6 \mathrm{Rxy} 1 \mathrm{H} 78)$.

Танцювальні артмоби (інколи можна зустріти назву flash dance) найчастіше виконуються під фонограму, що починає лунати «у незвичному місці у невідповідний час», а танцівники підключаються до загального виконання групами. Як правило, саме танцювальні артмоби відзначаються найчисленнішим контингентом учасників: якщо інструментальне та хорове виконавство передбачають участь виключно музикантів-професіоналів, то танцювальний артмоб з послідовністю нескладних рухів може бути організований та зрепетируваний $з$ десятками, сотнями і навіть тисячами учасників.

Дослідниця танцювальних артмобів О. Платонова зазначає, що, окрім ідеї «чистої творчості» та боротьби з нудьгою, такий артмоб може переслідувати й інші цілі, зокрема рекламні (просування певного танцювального стилю, презентація танцювальної школи) та соціальні (формування суспільної думки, комунікація між різними прошарками населення) [7, 48].

У 2009 р. на залізничному вокзалі бельгійського Антверпена відбувся чудовий флешденс: після звичайного вокзального дикторського тексту щодо прибуття/відправлення потягів раптом починає звучати пісня «До, ре, мі» $з$ легендарного мюзиклу «Звуки музики». Пасажири дещо здивовані, але що їх чекає далі! Раптом один чоловік починає танцювати, до нього приєднується дівчинка, потім ще двоє «пасажирів», ще і ще - i ось уже танцює майже весь вестибюль, полишивши на підлозі наплічники та інший багаж. Цікаво спостерігати, як реагують на танець справжні пасажири: радіють, посміхаються, фотографують, підспівують та підтанцьовують. Інформація в мережі стверджує, що ця акція була частиною рекламної кампанії бельгійського телебачення щодо кастингу однойменного мюзиклу (https://www. youtube. com/watch?v=bQLCZOG202k). 
Наймасовіший артмоб, в якому взяли участь близько 21 тисячі осіб і який завдяки цьому було занесено до Книги рекордів Гіннесса, відбувся 8 вересня 2009 р. у Чикаго на відкритті 24-го сезону знаменитого телевізійного шоу Опри Вінфрі. На відкритій сцені група Black Eyed Peas почала виконувати пісню «I Gotta Feeling» перед заповненою людьми площею. Спочатку перебільшені танцювальні рухи однієї дівчини перед сценою можуть здатися звичайним екстазом захопленої фанатки, але коли до неї поступово починають приєднуватися чимдалі більші групи «сусідів»розумієш, що так задумано. Наприкінці пісні вже багатотисячна площа існує у синхронному русі, а музиканти та Опра Вінфрі, що також перебуває на сцені, у здивованому захваті спостерігають за дійством: інформаційні ресурси стверджують, що артмоб став сюрпризом для ведучої (https://www. youtube. $\mathrm{com} / \mathrm{watch}$ ? $\mathrm{v}=\mathrm{rMyw} 17 \mathrm{XrVqU}$ ).

$\mathrm{У}$ статті наведено всього декілька прикладів, але сьогодні вже десятки чи навіть сотні інструментальних, вокальних та танцювальних артмобів у всьому світі виконано і зафіксовано для перегляду: кожний охочий може переглянути їх у мережі.

Головною особливістю у сприйнятті артмобу $€$ незвичність середовища для виконання мистецького твору: коли жива симфонічна музика лунає на ринку чи у вагоні метро, хоровий спів звучить у фаст-фуді, а танець розгортається у приміщенні залізничного вокзалу чи аеропорту, - випадковий глядач відчуває позитивне здивування, переживає момент казки, дива, адже у звичний темпоритм його буденного життя вторгається експресивна святковість.

Ще однією особливістю сприйняття артмобу, недоступною глядачеві на звичайному концерті, $\epsilon$ відчуття себе ніби всередині твору. Відеофіксація артмобів свідчить, що перехожі/пасажири/відвідувачі кафе тощо, опинившись у локації виконання артмобу, щиро занурюються у раптово створений арт-простір, долучаючись в той чи інший спосіб до виконавства: більшість глядачів починають пританцьовувати, плескати в долоні, підспівувати, «диригувати» тощо. Як влучно зазначила М. Веселова, артмоб є «інтегративною практикою, котра націлена і на створення арт-об'єкта, і на включення глядача як арт-об'єкта» $[1,80]$.

Отже, мистецька природа артмобу, що поєднує його як з іншими формами акціонізму, так і з видовищними мистецтвами (театром, кінематографом, телебаченням), виявляється у таких характерних рисах, як: самоцінність художнього процесу, демократизм, комунікативна спрямова- ність «на глядача», стирання грані між життям i мистецтвом, естетизація середовища і навіть творення нової реальності.

\section{Джерела та література}

1. Веселова М.Н. Арт-моб как инструмент взаимодействия человека с городской средой. Вестник Санкт-Петербургского государственного университета культуры и искусств. 2017. № 2 (31). С. 79-82.

2. Демченков С. А., Паршанина Н. С. Флешмоб как урбанистический феномен: социально-философский и коммуникативный аспекты. Омский научный вестник. 2015. № 1 (135). С. 75-78.

3. Демченков С. А., Паршанина Н. С. Флешмоб как форма массовой коммуникации: типология, прагматика и поэтика. Речевая коммуникация в современной России: материалы III Междунар. конф. Омск, 2013. С. 48-56.

4. Жаркова М. А. Молодёжный субпоток: особенности формирования, функционирования и трансформации в современном российском обществе (на примере флешмоба города Казани): автореф. дис. ... канд. социол. наук: спец. 22.00 .04 «Социальная структура, социальные институты и процессы». Саранск, 2013. 24 с.

5. Крылова А.В. Флешмоб и иные способы активизации массового потребления музыкальных форм искусства. Проблемы музыкальной науки. 2013. № 1 (12). С. 42-45.

6. Петренко-Лисак А.О.Теоретико-методологічній аналіз соціальних рухливостей: флешмобу, буккросінгу та паркуру. Актуальні проблеми соціології, психології, педагогіки. 2011. Вип. 12. С. 27-32.

7. Платонова О.А. Танцевальный флешмоб как социокультурное явление: экранный образ и внеэкранная реальность. Наука телевидения. 2017. № 13.4. С. 39-54.

\section{References}

8. Veselova, M. N. (2017). Art-mob kak instrument vzaimodeystviya cheloveka s gorodskoy sredoy. Vestnik Sankt-Peterburgskogo gosudarstvennogo universiteta kulturyi i iskusstv. № 2 (31). S. 79-82 [in Russian].

9. Demchenkov, S. A., Parshanina, N. S. (2015). Fleshmob kak urbanisticheskiy fenomen: sotsialno-filosofskiy i kommunikativnyiy aspektyi. Omskiy nauchnyiy vestnik. № 1 (135). S. 75-78. [in Russian].

10. Demchenkov, S. A., Parshanina, N. S. (2013). Fleshmob kak forma massovoy kommunikatsii: tipologiya, pragmatika i poetika. Rechevaya kommunikatsiya v sovremennoy Rossii: materialyi III Mezhdunar. Konf. Omsk. S. 48-56 [in Russian].

11. Zharkova, M. A. (2013). Molodyozhnyiy subpotok: osobennosti formirovaniya, funktsionirovaniya $\mathrm{i}$ transformatsii $\mathrm{v}$ sovremennom rossiyskom obschestve (na primere fleshmoba goroda Kazani): avtoref. dus. ... kand. sotsiol. n.: spets. 22.00 .04 «Sotsialnaya struktura, sotsialnyie institutyi i protsessyi». Saransk. 24 [in Russian].

12. Kryilova, A. V. (2013). Fleshmob i inyie sposobyi aktivizatsii massovogo potrebleniya muzyikalnyih form iskusstva. Problemyi muzyikalnoy nauki. № 1 (12). S. 42-45 [in Russian].

13. Petrenko-Lisak, A. O. (2011). Teoretiko-Metodologichniy analiz sotsialnih ruhlivostey: fleshmobu, bukkrosingu ta parkuru. Aktualni problemi sotsiologiyi, psihologiyi, pedagogiki. Vip. 12. S. 27-32 [in Ukrainian].

14. Platonova, O. A. (2017). Tantsevalnyiy fleshmob kak sotsiokulturnoe yavlenie: ekrannyiy obraz i vneekrannaya realnost. Nauka televideniya. № 13.4. S. 39-54 [in Russian]. 